July 2021

\title{
Tapping into food industry: A comparative dual-model study of religion and culture on food products' purchase intention
}

\author{
Sumera Syed \\ Universiti Teknologi Malaysia, sumera0005@gmail.com \\ Fauziah S. Ahmad \\ Universiti Teknologi Malaysia, fsa@utm.my \\ Syed R. H. Shah \\ The University of the West Indies, srhshah@gmail.com
}

Follow this and additional works at: https://digitalcommons.usf.edu/jometr

Part of the Hospitality Administration and Management Commons, and the Marketing Commons

\section{Recommended Citation}

Syed, S., Ahmad, F. S., \& Shah, S. R. (2021). Tapping into food industry: A comparative dual-model study of religion and culture on food products' purchase intention. Journal of Mediterranean Tourism Research, 1(1), 1-11. https://www.doi.org/10.5038/2770-7555.1.1.1001

Corresponding Author

Sumera Syed, House No. 30, Shaheen Block, Sector B-Bahria Town, Lahore-53720 Pakistan

Revisions

Submission date: April. 17, 2021; 1st Revision: April. 21, 2021; Acceptance: July. 14, 2021 


\title{
Tapping Into Food Industry: A Comparative Dual-Model Study of Religion and Culture on Food Products' Purchase Intention
}

\section{Sumera Syed ${ }^{1}$, Fauziah Sh. Ahmad², and Syed Rashid Hussain Shah $^{3}$}

\author{
Azman Hashim International Business School \\ Universiti Teknologi Malaysia, Kuala Lumpur, Malaysia \\ ${ }^{1}$ sumera0005@gmail.com \\ ${ }^{2}$ fsa@utm.my \\ ${ }^{3}$ Faculty of Social Sciences \\ The University of the West Indies, St. Augustine, Trinidad and Tobago \\ ${ }^{3}$ srhshah@gmail.com
}

\begin{abstract}
Due to increased trend of globalization and immigration to advanced countries during the past decade, Halal food consumers are being observed not only in Islamic countries but also in Western European countries. Moreover, the concepts of hygiene, quality and cleanliness, being often related to Halal food, make it equally favorable for consumption to non-Muslims. However, this vast area of Halal food sector still needs further exploration. Though recent studies have, to some extent, tried to explore the impact of religiosity on Halal food purchase intention, but still the impact of religion on Halal food purchase intention remains unexplored. Moreover, almost no studies are available on the impact of culture in making Halal food purchase intention. Therefore, the study aims at understanding the influence of culture and religion along with attitude on Halal food purchase intention. The direct impacts of culture, religion and attitude on Halal food have been presented in the proposed framework. In addition, the conceptual model depicts examining the impact of culture and religion on Halal food purchase intention through mediation, with attitude as a mediating variable. Moreover, the study recommends conducting the comparison of the impact of religion and culture on Halal food purchase intention. Managerial implications and future recommendations have also been incorporated.
\end{abstract}

Keywords: religion, culture, attitude, purchase intention, halal food

\section{Introduction}

Muslim population is reckoned to cross 2 billion by 2030, making up about $26.4 \%$ of the world population (Pew Research Centre, 2011); subsequently, the businesses are expected to get influenced mainly by the population. (Zailani et al., 2015). It is evidently revealed by the literature that among other factors, religion remains the strongest influencer and determinant for consumer behavior in regard to food purchases (Essoo \& Dibb, 2010; Jalil et al., 2018). The followers of Islam are keenly observing the instructions and parameters set by Islam about making their food choices and purchase decisions (Awan et al., 2015). Researchers have explained the content of the 
terms in multiple disciplines including religion that qualifies to ascertain, while building better understanding for the followers in their daily life matters. The same plays a role of guidance for the individuals while making food choices and managing other matters of individuals every day (Riaz \& Chaudhry, 2004).

The term Halal food would be used in the present study because aside from its growing worldwide acceptance, Halal is equally known to both Muslim and non-Muslim communities (AtalanHelicke, 2015). Moreover, apart from Muslim countries, Halal food industry is gaining equal popularity in majority of non-Muslim countries. Alone in USA, the spending on Halal meat in 2016 was recorded at \$20 billion on Halal food which is $33 \%$ more than the spending in 2010 (Islamic Services of America, 2019). Besides a report issued by IMARC group (2021) states that US\$ 1.9 trillion were globally spent in Halal food sector during the year 2020. Among other reasons of growth for Halal food markets, one key factor is the growing population of Muslims across the globe (Abdul-Talib \& Abd-Razak, 2013; Lever \& Miele, 2012). Moreover, a significant increase in the consumption of Halal food market is indicated by the Pew Research Center (2018), based mainly on the $35 \%$ increase in Muslim population by 2030 , predicting a generation of massive demand of meeting the needs of Halal food in global food markets. Nevertheless, another important factor is 'continuously increasing purchasing power' of Muslims that contributes greatly to the growth of Halal food purchases (Muslim Ad Network, 2019). Moreover, the perception of consuming more quality food with respect to its safety and hygiene is another appealing factor also for non-Muslims; thus, results into more demand and subsequently more growth for the Halal food markets.

Businesses have recently recognized the importance of attracting the Muslim majorities by making a major shift in their production and marketing strategies to highlight the Halal food possession, in order to be competitive and more sustainable (Fischer, 2012). Emphasizing the importance of adopting new business practices by multinational companies, it is observed that the businesses are now adopting more acceptable practices for the potential consumer segments. Hence, Halal branding has emerged as one of the most focused area of concentration by the businesses, since they do not solely rely on local consumer markets but expand their target markets through export to the regions such as i.e., Middle East and South Asian countries (Masron et al., 2014). Halal food market is being reported as one of the largest and growing food markets globally (Thomson Reuters, 2018). Razzaque and Chaudhry (2013) explained that irrespective of majority or minority, the Muslims tend to consume only Halal food, and hence, the Halal food industry is expected to grow even bigger over the years. Besides, it is also noted that the increase in consumption of Halal food is not only reported in Muslim majority countries but also non-Muslim states in different continents of the world, such as Europe, South America and Asia-Pacific (Ali et al., 2017; Kabir, 2015). Furthermore, consumers are paying more attention to healthier foods, whereby quality and safety remain an integral part of healthy food perception by the consumers (Khalek \& Ismail, 2015), the same emerged as the most significant reason for the popularity of Halal products among non-Muslim market segments as well (Ambali \& Bakar, 2014). Furthermore, many food giants have started offering Halal food products out of an overwhelming tendency among consumers to intend for purchasing Halal food products, even in countries with non-Muslim majority (BergeaudBlackler, 2007; Wilkins et al., 2019). Moreover, alone in UK, a massive number of superstores are currently offering Halal food products; so besides Muslims, non-Muslims are also becoming familiar and consumers of Halal food products (Fuseini et al., 2017). 
Furthermore, the geographical confinement of Halal food market only to the Muslim countries is a gone concept now, as many non-Muslim countries have become part of this competition not only by producing but also exporting Halal products to other countries as well (Dasgupta, 2011). Dasgupta (2011) further points out that in the near future, China and Thailand will become key players in producing and exporting Halal food products globally. Moreover, the establishment of Halal DistriPark in Rotterdam and Super Halal Industrial Park in South Wales witness that besides other continents, Europe is also getting popular due to its Muslim consumers (Waarden \& Dalen, 2010). Calcinai (2007) analyzes that New Zealand emerged as one of the largest exporters of Halal lamb meat and also counted as the major meat exporter, primarily to the Middle East market. New Zealand Islamic Meat Management Report (2009) shows that about 98\% lamb meat and $60 \%$ cattle meat being slaughtered is Halal in New Zealand.

Power (2009) argues that the one main reason for Muslims to buy and eat only Halal food is the obligation by their religion Islam while non-Muslims tend to buy and consume Halal food because they perceive it safer and more hygienic. Ali et al. (2017) discuss that irrespective of the place of living, Muslims always intend to buy and consume only Halal food. However, it is also evidently seen that Muslims are more conscious about the credibility of the food source, especially if they are residing or visiting a non- Muslim country. Verbeke et al. (2013) study that a common perception prevails among the consumers that if the owner of a Halal food outlet is Muslim, the product is commonly assumed to be Halal too. However, in case of having an owner of Halal food restaurant as non-Muslim, the Muslim consumers tend to ensure the credibility and reliability of a food as Halal through some type of assurance, i.e., a Halal label or logo. Nevertheless, it is now agreed that all Halal products must get declaration from the respective Islamic bodies (Asa, 2019).

Parallel to that, it is also significantly evident that cultural beliefs and traditions are quite instrumental in influencing the consumer food buying behavior (Alonso-Alonso et al., 2015; Shipman \& Durmus, 2017). However, there is not much work done on investigating the impact of culture especially on Halal food products. This study, therefore, focuses on the impact of both the religion and culture on Halal food buying and consumption behavior as well as an analysis of whether Halal food buying, and consumption is more influenced by religion or is it the culture which has greater influence?

\section{Literature Review}

\section{The Term Halal}

Any act that is permitted in Islam is considered as Halal (Muhammad et al., 2009; Riaz \& Chaudhry, 2004). On the contrary, whatever Muslims are forbidden to do is named Haram as per Islamic laws (Alam \& Sayuti, 2011). As per Muslims' belief, the authority to set a certain criterion for Halal and Haram is only Allah (Tieman \& Hassan, 2015) However, at times there are certain acts those may create certain confusion among the followers, all such should be avoided. However, Kamali (2010) states that all such matters are to be decided as per the discretion of local fatwas or Islamic School of thought, importantly keeping themselves into the limitations defined and set by Islam through Quran and its Prophet Muhammad. The concept of Halal is certain bounding for Muslims that is not restricted only to food purchase and consumption but also for other everyday matters of life (Thomas \& Selimovic, 2015). However, this study is particularly focused on the concept of Halal with regard to the purchase and consumption of food products only. 


\section{Underpinning Theory}

Behavior is regarded as the activity being carried out by an individual and has been explained by most of the researchers by using Theory of Reasoned Action (TRA) developed by Ajzen and Fishbein (1980). TRA states that attitude and subjective norms act as the determinants of intention and behavior. Attitude is described as the individual's positive and negative assessment of behavior; subjective norms, on the other hand, are the perceptions of an individual that his behavior would be accepted or rejected by people important to him (Ajzen \& Fishbein, 1980). TRA has been used by many researchers to examine Halal food purchase intention. Hussain et al. (2016) applied TRA in a study conducted in Pakistan and find a positive relationship between attitude and Halal products purchase intention. Bashir (2019) identifies a positive attitude of South African consumers on Halal food purchase intention. Suleman et al. (2021) also discover that a positive attitude enhances Halal food purchase intention which is consistent with the study conducted by Cheung and To (2019). The above discussion leads to the proposition:

- Proposition 1: Consumers' positive attitude enhances their Halal food purchase intention.

\section{Impact of Religion on Halal Food Purchase Intention}

Religion is a composition of beliefs and practices followed by a certain group of individuals under the inspiration or faith in a super-natural power (Morreall et al., 2013). However, these beliefs and practices have both internal and external elements (Allport \& Ross, 1967). Internal factors of religiosity make the basis for the formation of attitudes, beliefs and values, while external factors are related to activities such as going to church, performing religious rituals and taking part in religious ceremonies (Ibrahim \& Ismail, 2015).

Ibrahim and Ismail (2015) further argue that cognitive and behavioral influences of religion on the individuals affect their purchase making decisions. Henceforth, mostly the buying behaviors, specifically the food purchase decisions in any setting, seem to be highly influenced by a particular set of thoughts and importantly by religion (Blackwell et al., 2001; Pettinger et al., 2004). Tieman and Hassan (2015) discuss that every religion has set certain dietary laws pertaining to food system like Muslims eat only Halal food while Jews abide by following Kosher dietary laws which are based on holiness. Nonetheless, Christians would follow food laws from Old Testaments which were same as Jewish laws, but now Christians eat and drink everything based on the teachings of Paul who allowed eating and drinking everything except the meat of animals sacrificed to idols. Sack (2001) also studied that the Jews and Muslims are not allowed to consume pork; whereas Hindus and Buddhists should not eat pork and beef as per the teachings of their religions; while Christians seemed to allow everything, related to food practices. However, Delener (1994) argues that despite every religion exerts a certain pressure on its followers that significantly impacts their daily lives, still it is not clear that to what extent it actually affects the food purchase decisions of individuals. However, he agrees that the religion itself and the following of its teachings by its followers are two vital components that significantly affect the food choice of its followers. Bonne et al. (2007) study that every religion has set different rules in regard to the selection of food choices. According to a study conducted in US by Hussaini (1993), about 75 percent of Muslims follow their religious teachings relating to food consumption in comparison with only 16 percent of Jews abiding by dietary laws set by Judaism. Social factors such as immigration and generation gap are the main reasons for the differences in practicing dietary rules set by a particular religion 
(Ababou, 2005; Bergeaud-Blackler, 2001; Limage, 2000). Mokhlis and Spartks (2007) also study that for those who are true followers of their respective religions, the religion has a significant impact on the purchase decisions of those individuals. Hence, the proposition is formulated as:

- Proposition 2: Consumers' religion positively impacts their Halal food purchase intention.

\section{Impact of Culture on Halal Food Purchase Intention}

Geertz (1973) defines culture as the practices and norms followed collectively by a group of individuals which ultimately result in the formation of a distinct society. Hence, the members of a specific culture share a common set of traditions, values and beliefs which are not shared by other groups.

Shipman and Durmus (2017) identify that apart from religion, culture and traditional knowledge are also two main factors influencing food choice decisions. They also find that there are some traditions along with religion which prohibit one from buying and consuming different foods. In a study performed on Muslims in Turkey, they analyzed that culture significantly impacts the food consuming behavior of Muslims, especially in Ramadan. Oosterveer (2006) studies that background history and culture can easily be determined by looking at food consumption pattern of the citizens of a relevant country. He further studies that meal timings and food ingredients are different in every culture. Penaloza (1994) and Reilly and Wallendorf (1987) argue that food cultures are indicative of the people's expressions, and cultural, ethnic and individual identities. Mintz (1996) and Mitchell (2009) emphasize that food culture is an indicative of historical events, customs and traditional beliefs. The consumption of traditional foods is being characterized by as an ethnic identity, like eating dates in Ramadan. Hughes (1997) and Shipman and Durmus (2017) infer that the demand for certain foods, their preparation and serving, and eating practices are dependent upon food culture. Monin and Szczurek (2014) argue that new generations get aware of their food culture and traditions like Ramadan and the two festivals of Eid, by their family. They further study that though food is the main factor in getting an understanding of the values, beliefs and traditions of a society; but the food choices vary from society to society because of religion, beliefs and ethnicity. Shipman and Durmus (2017) study that a lot of people eat certain foods because it reminds them of their family or some special days or childhood (De Bourdeaudhuij, 1997). A study conducted in Hamilton (New Zealand) by Longhurst et al. (2010) shows that the migrant women feel happy when they cook their traditional dishes in their new homeland as they get the feeling of still being connected by their native country. Moreover, a study performed in England by Lindgreen and Hingley (2012) reveals that South-East Asian students experience deep emotional shock related to food because of significant differences in their home and local food. They further note that first the students were willing to try local food, but they found it less spicy and tasteless. They further argue that the students confessed that this negative response to local food was due to the cultural differences in food tastes. They conclude that though a few students showed their willingness to try different ethnic foods, but the majority showed their determination to follow the dietary practices of their home country. The discussion may result in a proposition that:

- Proposition 3: Consumers' culture influences their Halal food purchase intention. 


\section{Impact of Religion on Attitude}

TRA is based on the assumption that consumers' attitude and subjective norms are influenced by a number of factors, religion being one of them (Ajzen \& Fishbein, 2005). Religion refers to a broader prospect comprising of beliefs, doctrines and worship rituals etc. which help develop personal values (Fry et al., 2011). Ajzen and Fishbein (1980) argue that attitudes lay their foundations in values and beliefs. In addition, Essoo and Dib (2004) examine that consumers' attitudes towards food products are largely influenced by their religious beliefs. Henceforth, the proposition may be established as:

- Proposition 4: Consumers' religion positively influences their attitude towards any decision making.

\section{Impact of Culture on Attitude}

Muller (2005) defines culture as the whole complex of traditional behavior, which has been improved by the human race and is successively learned by each generation. He further describes that culture is not inherited but it is a concept, learned from generation to generation in the form of stories, values and beliefs. Brom et al. (2020) study that social forces specifically cultural norms shape up attitudes. Evans-Lacko and Knapp (2014) discover the role of socio-cultural settings in the formation of attitudes in workplace setting. Beltrán et al. (2016) argue that people prefer things from their immediate environment, and they don't accept things rejected by their parents, family or friends; mainly due to the risk associated with trying new things. However, they analyze that older people are more reluctant to try new foods as compared to the general youngsters, may be because of their long attachment to their customs and traditions. Hence, the discussion may infer that the cultural values and beliefs of consumers shape up their attitudes towards food purchase decisions (Ajzen \& Fishbein, 1980). Hence, the postulate may be derived as:

- Proposition 5: Consumers' living culture has a positive influence on their attitude towards Halal food purchase intention.

\section{Consumers' Attitude as a Mediator}

The earlier discussion highlights the direct relationships of religion and culture with Halal food purchase intention. However, as consumers' attitude is also shaped up by religion and culture as discussed earlier, hence, it could be concluded that attitude may work as a catalyst for the relationship of religion and culture with Halal food purchase intention. Therefore, the propositions are formulated as following:

- Proposition 6: Consumers' attitude mediates the relationship between religion and Halal food purchase intention.

- Proposition 7: Consumers' attitude mediates the relationship between culture and Halal food purchase intention. 


\section{Whether Culture Impacts Food Purchase Decisions More or Is It Religion?}

Fieldhouse (1995) argues that though both religion and culture have an impact on food choice decisions, but as culture is dynamic and changing, and religion is somehow rigid and unchangeable, so religion has more impact on food choice decisions. Almost no literature comprising of comparative study of religion and culture regarding Halal food purchase intention is available. However, based on the study carried out by Fieldhouse (1995), it may be postulated that:

- Proposition 8: Consumers' religion has more influence on their Halal food purchase intention as compared to the culture they are living in.

\section{Conceptual Framework}

Figure 1: Conceptual Model

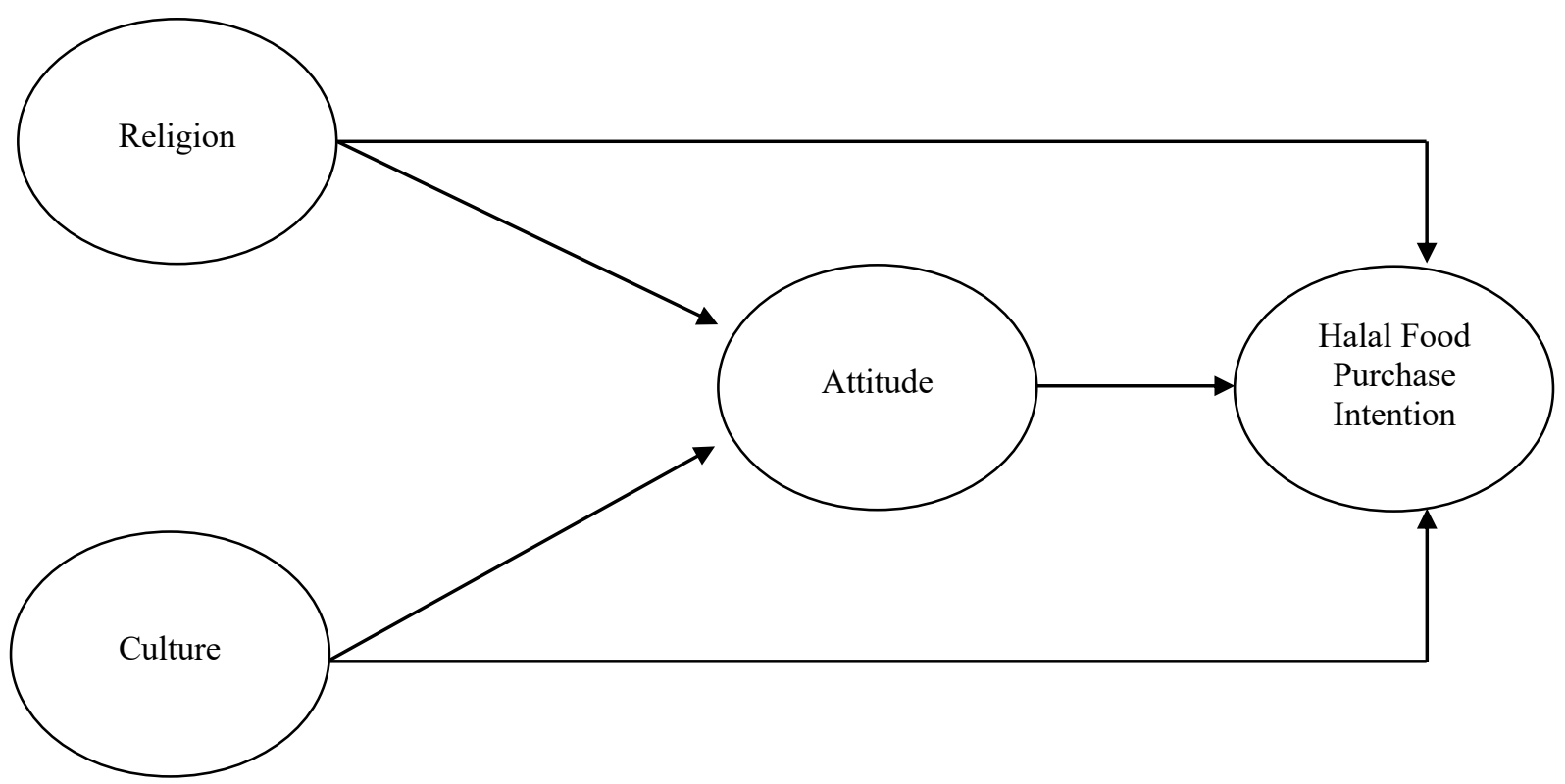

\section{Conclusion}

This study highlights the direct and indirect relationship between highly influenced factors such as i.e., religion, and culture on consumers' attitude formation for building Halal food purchase intentions. As the literature suggested, the significance of direct relationship between religion and Halal food purchase intention is very high. Many studies had evidently discussed the notion that consumers have a positive tendency to get influenced due to their religious obligations and following these obligations. Moreover, the formation of positive intention to purchase Halal food is commonly observed among consumers' attitudes. There are multiple factors playing important role in enhancing the positive attitude of consumers, whereby culture serves the role of catalyst. Primarily the attitudes are formed in a given setting of environment that impacts the individuals' thoughts and urge them to have a sense of belongingness with others, through sharing the same norms, values, and rituals. The need of an individual of not being alone enforces the trajectory towards same attitude formation, as of others in a particular socio-cultural setting. Interestingly, 
the religion and culture have been rarely studied together in respect to have any influence on the attitude formation of consumers for Halal food purchase intention. This study tries to create a significance of this relationship in a comparative framework for the very first time. However, the past studies indicated that at times attitude does play a mediating role between religion and culture in which personal norms were being identified and Halal food purchase intentions. This study shares a multidimensional conceptual framework that subsequently offers the opportunity to testify the impact of religion and culture on consumers' Halal food purchase intention, whereby the comparative significance is not only possible but also provide new perspective to build better understanding of the consumers' attitude formation.

\section{Managerial Implications}

The digital revolution has largely enforced organizations to make the smart and strategic moves, as per the diversified need of the geographically distant consumers. Hence, organizations are highly engaged on designing the products offerings and services as per the changing needs of their consumers living in different continents of the world. The fact is that digitalization of businesses has played a great role in the growth of organizations and their profits in manifolds, whereby making it possible to serve the geographically scattered consumers with standardized product offerings. However, at the same time this phenomenon brought many challenges too for the organizations. Since, consumers' decision to purchase any product is heavily dependent on the environmental situations as well as the individuals certain set of beliefs. This holds very true, if the purchase of a product is addressed specifically by the triggering force of consumers' set of belief such as religion. Therefore, it is suggested that organizations should try to understand the real reasons behind any attitude of the consumers. Because the better understanding of the real cause of the triggering force, which shapes up consumers' attitude will help organizations to design their services and offerings accordingly.

\section{Recommendations for Future Research}

Religion and culture are two very broad social phenomenon influencing all the aspects of our everyday lives. However, the present study is limited to only general concepts of religion and culture and aims at exploring Halal food purchase intention of individuals belonging to different religious groups and different cultures. Whereas the study of religion mainly involves the extent to which the followers of that particular group obey its teachings, commonly known as religiosity which has two main dimensions i.e., intrinsic and extrinsic religiosity. Likewise, culture has very popular dimensions as presented by Hofstede (1980), among them are collectivism and individualism very well-known. Nonetheless, the present study doesn't give an insight into these popular dimensions of religion and culture. The future researchers are recommended to explore Halal food purchase intention with regard to these broader aspects of religion and culture.

Furthermore, the study gives a conceptual framework to understand the impact of culture and religion on Halal food purchase intention; the researchers may use the presented conceptual framework to empirically analyze the model in future. In addition, the study has used only the component attitude of TRA, the other component subjective norms may also be included in future studies. Nevertheless, other consumer behavior and psychological theories may also be applied on the proposed conceptual model to understand consumers' Halal food purchase intention. 


\section{References}

Ababou, M. (2005). The impact of age, generation and sex variables on religious beliefs and practices in Morocco. Social Compass, 52(1), 31-44.

Abdul-Talib, A. N., \& Abd-Razak, I. S. (2013). Cultivating export market-oriented behavior in halal marketing: Addressing the issues and challenges in going global. Journal of Islamic Marketing, 4(2), 187-197.

Ajzen, I., \& Fishbein, M. (1980). Understanding attitudes and predicting social behavior. Prentice Hall.

Ajzen, I., \& Fishbein, M. (2005). The influence of attitudes on behavior. In D. Albarracin, B. T. Johnson, \& M. P. Zanna (Eds.), The handbook of attitudes (pp: 173-221). Erlbaum.

Alam, S. S., \& Sayuti, N. M. (2011). Applying the theory of planned behaviour (TPB) in Halal food purchasing. International Journal of Commerce and Management, 21(1), 8-20.

Ali, A., Xiaoling, G., Sherwani, M., \& Ali, A. (2017). Factors affecting Halal meat purchase intention: Evidence from international Muslim students in China. British Food Journal, 119, 527-541.

Allport, G. W., \& Ross, J. M. (1967). Personal religious orientation and prejudice. Journal of Personality and Social Psychology, 5(4), 432-443.

Alonso-Alonso, M., Woods, S. C., \& Pelchat, M. (2015). Food reward system: Current perspectives and future research needs. Nutrition Reviews, 73(5), 296-307.

Ambali, R. A., \& Bakar, A. N. (2014). People's awareness on halal foods and products: Potential issues for policymakers. Procedia - Social and Behavioral Sciences, 121, 3-25.

Asa, R. S. (2019). An overview of the developments of Halal certification laws in Malaysia, Singapore, Brunei and Indonesia. Jurnal Syariah, 27(1), 173-200.

Atalan-Helicke, N. (2015). The halal paradox: Negotiating identity, religious values, and genetically engineered food in Turkey. Agriculture \& Human Values, 32(4), 663-674.

Awan, H. M., Siddiquei, A. N., \& Haider, Z. (2015). Factors affecting Halal purchase intention-evidence from Pakistan's Halal food sector. Management Research Review, 38(6), 640-660.

Bashir, A. M. (2019). Effect of halal awareness, halal logo and attitude on foreign consumers' purchase intention. British Food Journal, 121(9), 1998-2015.

Beltrán, L. S., Gómez, D. M. C., \& León, J. D. (2016). The Mexican consumer, reluctant or receptive to new foods? British Food Journal, 118(3), 734-748.

Bergeaud-Blackler, F. (2007). New challenges for Islamic ritual slaughter: A European perspective. Journal of Ethnic and Migration Studies, 33(6), 965-980.

Blackwell, R. D., Miniard, P. W., \& Engel, J. F. (2001). Consumer behavior. Harcourt College.

Bonne, K., Vermeir, I., Bergeaud-Blackler, F., \& Verbeke, W. (2007). Determinants of halal meat consumption in France. British Food Journal, 109(5), 367-386.

Brom, P., Anderson, P., Channing, A., \& Underhill, L. G. (2020). The role of cultural norms in shaping attitudes towards amphibians in Cape Town, South Africa. PLoS ONE 15(2), 1-18. https://doi.org/10.1371/journal.pone.0219331.

Calcinai, A. (2007). Halal accounts for 20\% of exports, straight furrow, Auckland. Straightfurrow. http://straightfurrow.farmonline.co.nznews_daily.asp?ag_id=45630.

Cheung, M. F., \& To, W. (2019). An extended model of value-attitude-behavior to explain Chinese consumers' green purchase behavior. Journal of Retailing and Consumer Services, 50, 145-153.

Dasgupta, S. (2011). China makes dent in halal market with 1/8th of India's Muslim population. The Times of India. http://articles.timesofindia.indiatimes.com/2011-09-21/china/30183710_1_halal-china- countries.

De Bourdeaudhuij, I. (1997). Perceived family members' influence on introducing healthy food into family. Health Education Research, 12, 77-90.

Delener, N. (1994). Religious contrasts in consumer decision behaviour patterns: Their dimensions and marketing implications. European Journal of Marketing, 28(5), 36-53.

Essoo, N., \& Dibb, S. (2004). Religious influences on shopping behavior: An exploratory study. Journal of Marketing Management, 20(7-8), 683-712.

Evans-Lacko, S., \& Knapp, M. (2014). Importance of social and cultural factors for attitudes, disclosure and time off work for depression: findings from a seven country European study on depression in the workplace. PloS One, 9(3), 1-18. https://doi.org/10.1371/journal.pone.0091053

Fieldhouse, P (1995). Food and nutrition: Customs and culture. Chapman \& Hall Ltd.

Fischer, J. (2012). Branding halal: A photographic essay on global Muslim markets. Anthropology Today, 28(4), 1821. 
Fry, L.W., Hannah, S. T., Noel, M., \& Walumbwa, F. O. (2011). Impact of spiritual leadership on unit performance. The Leadership Quarterly, 22(2), 259-270.

Fuseini, A., Wotton, S. B., Knowels, T. G., \& Hadley, P. J. (2017). Halal meat fraud and safety issues in the UK: A review in the context of the European Union. Food Ethics, 1(2), 127-142.

Geertz, C. (1973). The interpretation of cultures. Basic Books.

Hofstede, G. (1980). Culture's consequences: International differences in work-related values. Sage.

Hughes, M. (1997). Soul, black women and food. In C. Counihan, \& P. van Esterick (Eds.), Food and culture (pp. 272-280). Routledge.

Hussain, I., Rahman, S., Zaheer, A., \& Saleem, S. (2016). Integrating factors influencing consumers' Halal products purchase: Application of theory of reasoned action. Journal of International Food \& Agribusiness Marketing, 28(1), 35-38.

Hussaini, M. M. (1993). Islamic dietary concepts and practices. The Islamic Food and Nutrition Council of America.

Ibrahim, H., \& Ismail, H. (2015). A generational cohort study of the relationship between religious intensity and religious assurance for the purchase of non-food products. International Journal of Economics and Financial Issues, 5(1), 330-334.

IMARC Group. (2021). Halal food market: Global industry trends, share, size, growth, opportunity and forecast 2021-2026. https://www.imarcgroup.com/halal-food-market

Islamic Services of America (2019). Scope of the Halal food industry in USA. Isahalal. https://www.isahalal.com/news-events/blog/scope-of-Halal-food-in-USA

Jalil, N. S. A., Tawde, A. V., Zito, S., Sinclair, M., Fryer, C., \& Idrus, Z. (2018). Attitudes of the public towards halal food and associated animal welfare issues in two countries with predominantly Muslim and nonMuslim populations. PLoS ONE 13(10), 1-18. https://doi.org/10.1371/journal.pone.0204094

Kabir, S. (2015). Growing Halal meat demand: Does Australia miss out a potential trade opportunity? Economic Papers: A Journal of Applied Economics and Policy, 3(1/2), 60-75.

Kamali, M. H. (2010). The halal industry from a shariah perspective. Islam and Civilisational Renewal, 1(4), 595612.

Khalek, A. B. A., \& Ismail, S. H. S. (2015). Why are we eating halal-using the theory of planned behavior in predicting halal food consumption among generation Y in Malaysia. International Journal of Social Science and Humanity, 5(7), 608-612.

Lever, J., \& Miele, M. (2012). The growth of halal meat markets in Europe: An exploration of the supply side theory of religion. Journal of Rural Studies, 28(4), 528-537.

Limage, L. J. (2000). Education and Muslim identity: The case of France. Comparative education, 36(1), 73-94.

Lindgreen, A., \& Hingley, M. K. (2012). The new cultures of food: Marketing opportunities from ethnic, religious and cultural diversity. Gower.

Longhurst, R., Johnston, L., \& Ho, E. (2010). A visceral approach: Cooking 'at home' with migrant women in Hamilton, New Zealand. Transactions of the Institute of British Geographers, 34(3), 333-345.

Masron, T. A., Azman, N. H. N., \& Hassan, S. H. (2014). Halal development and food exports: Evidence from Malaysia and the Middle Eastern Asian countries, Journal Ekonomi Malaysia, 48(2). 61-69.

Mintz, S. W. (1996). Tasting food, tasting freedom: Excursions into eating, culture, and the past. Beacon.

Mitchell, W. F. (2009). African American food culture. Greenwood.

Mokhlis, S., \& Spartks, L. (2007). Consumer religiosity and shopping behaviour in Kuala Lumpur. Malaysian Management Journal, 11(1/2), 87-101.

Monin, B., \& Szczurek, L. M. (2014). Food and culture. In B. Adam Cohen (Eds.), Culture reexamined: Broadening our understanding of social and evolutionary influences (pp. 155-190). American Psychological Association.

Morreall, J., \& Tamara, S. (2013). Myth 1: All societies have religions.50 great myths of religion. Wiley-Blackwell.

Muhammad, N. M. N., Isa, F. M., \& Kifli, B. C. (2009). Positioning Malaysia as Halal-hub: Integration role of supply chain strategy and halal assurance system. Asian Social Science, 5(7), 44-52.

Muller, A. (2005). Concepts of culture art, politics and society. University of Calgary.

Muslim Ad Network (2019). Muslim consumer market is expanding: Be aware of the new Muslim consumer Landscape. Muslimadnetwork. https://www.muslimadnetwork.com/2019/09/20/muslim-consumer-marketis-expanding-be-aware-of-the-new-muslim-consumer-landscape/

New Zealand Islamic Meat Management. (2009). New Zealand meat processing industry, Muslim league of New Zealand. Muslimleague.http://www.muslimleague.org.nz/modules/wfchannel/index.php?pagenum=4. 
Oosterveer, P. (2006). Globalization and sustainable consumption of shrimp: consumers and governance in the global space of flows. International Journal of Consumer Studies, 30(5), 465-476.

Penaloza, L. (1994). Atravensando fronteras/border crossings: A critical ethnographic exploration of the consumer acculturation of Mexican immigrants. Journal of Consumer Research, 21(1), 32-54.

Pettinger, C., Holdsworth, M., \& Gerber, M. (2004). Psycho-social influences on food choice in Southern France and Central England. Appetite, 42(3), 307-316.

Pew Research Center. (2011). The future of the global Muslim population: Projections for 2010-2030. Pewforum. www.pewforum.org/files/2011/01/FutureGlobalMuslimPopulation-WebPDF-Feb10.pdf

Pew Research Center. (2018). Why Muslims are the world's fastest-growing religious group. Pew Research. https://www.pewresearch.org/fact-tank/2017/04/06/why-muslims-are-the-worlds-fastest-growing-religiousgroup/

Power, C. (2009, 15 May). Halal: Buying Muslim. ContentTime. http://content.time.com/time/subscriber/article/0,33009,1902837,00.html.

Razzaque, M. A., \& Chaudhry, S. N. (2013). Religiosity and Muslim consumers' decision-making process in a nonMuslim society. Journal of Islamic Marketing, 4(2), 198-217.

Reilly, M., \& Wallendorf, M. (1987). A comparison of group differences in food consumption using household refuse. Journal of Consumer Research, 14(2), 289-294.

Riaz, M. N., \& Chaudry, M. M. (2004). Halal food production. CRC.

Sack, D. (2001). Whitebread Protestants. food and religion in American culture. Palgrave Macmillan.

Shipman, D., \& Durmus, B. (2017). The effect of culture on food consumption: A case of special religious days in Turkey. Journal of Food Research, 6(2). 92-97.

Suleman, S., Sibghatullah, A., Azam, M., \& Pantea Foroudi, P. (2021). Religiosity, halal food consumption, and physical well-being: An extension of the TPB. Cogent Business \& Management, 8(1), 1-18. https://doi.org/10.1080/23311975.2020.1860385

Thomas, P., \& Selimovic, A. (2015). Sharia on a plate? A critical discourse analysis of halal food in two Norwegian newspapers. Journal of Islamic Marketing, 6(3), 331-353.

Thomson Reuters. (2018). Global halal food consumption market report 2018-2023. Orbisresearch. http://www.orbisresearch.com/reports/index/2018-2023-global-halal-food-consumption-market-report

Tieman, M., \& Hassan, F. H. (2015). Convergence of food systems: Kosher, Christian and Halal. British Food Journal, 117(9), 2313-2327.

Verbeke, W., Rutsaert, P., Bonne, K., \& Vermeir, I. (2013). Credence quality coordination and consumers' willingness-to-pay for certified Halal labelled meat. Meat Science, 95(4), 790-797.

Waarden, F. V., \& Dalen R. V. (2010, June 17-19). Hallmarking HalalThe market for Halal certificates: Competitive private regulation [Conference Presentation]. Third Biennial Conference of the ECPR Standing Groups on Regulation and Governance, Dublin, Ireland. http://regulation.upf.edu/dublin-10papers/5F3.pdf

Wilkins, S., Butt, M. M., Shams, F., \& Pérez, A. (2019). The acceptance of halal food in non-Muslim countries: Effects of religious identity, national identification, consumer ethnocentrism and consumer cosmopolitanism. Journal of Islamic Marketing, 10(4), 1308-1331.

Zailani, S., Kanapathy, K., Iranmanesh, M., \& Tieman, M. (2015). Drivers of halal orientation strategy among halal food firms. British Food Journal, 117(8), 2143-2160. 